\title{
Uredospore germination of Hemileia vastatrix and its inhibition by the effect of plant extracts in vitro
}

\author{
Miguel A. Morales-Antonio', Gisela M. Santiago-Martínez ${ }^{1}$, Alfonso \\ Vásquez-López ${ }^{2}$, Gerardo Rodríguez-Ortiz ${ }^{1}$, Delia Soto-Castro², Salvador \\ Lozano-Trejo $^{1}$, and Ernesto Castañeda-Hidalgo ${ }^{1}$ \\ ${ }^{1}$ Instituto Tecnológico del Valle de Oaxaca/Tecnológico Nacional de México. Ex Hacienda de Nazareno, \\ Santa Cruz Xoxocotlán, 71230, Oaxaca, México. \\ ${ }^{2}$ Instituto Politécnico Nacional. CIIDIR Unidad Oaxaca. Hornos 1003, Col. Noche Buena; Santa Cruz \\ Xoxocotlán, 71230. Oaxaca, México.
}

\begin{abstract}
M.A. Morales-Antonio, G.M. Santiago-Martínez, A. Vásquez-López, G. RodríguezOrtiz, D. Soto-Castro, S. Lozano-Trejo, and E. Castañeda-Hidalgo. 2021. Uredospore germination of Hemileia vastatrix and its inhibition by the effect of plant extracts in vitro. Int. J. Agric. Nat. Resour. 108-114. Coffee leaf rust, caused by Hemileia vastatrix, is the most important disease of coffee (Coffea arabica L.) in Mexico. It causes production losses of up to $40 \%$ and leads to the use of considerable volumes of synthetic fungicides. The main goals of this research were to identify the temperature, $\mathrm{pH}$, incubation time, and luminosity required for in vitro germination of $H$. vastatrix uredospores and to evaluate the effect of plant extracts on their germination. Uredospores from coffee plants (var. Caturra) grown in the state of Oaxaca, Mexico, were collected and subjected to treatments consisting of combined levels of $\mathrm{T}^{\circ}, \mathrm{pH}$, and incubation time. The treatments were evaluated in darkness and under low-intensity white light $(15 \mathrm{~W})$. Uredospore germination occurred in the absence and presence of light. The highest percentage of uredospore germination was $44.95 \%$, which occurred at $\mathrm{pH} 5.7$, between 18 and $24{ }^{\circ} \mathrm{C}$, and with an incubation time of $24 \mathrm{~h}$. The effect of 30 plant extracts was evaluated in terms of inhibition of uredospore germination. The acetone and ethanol extracts of Tribulus terrestris, Datura ferox, Mansoa alliacea, Ricinus communis, and Acacia farnesiana inhibited $100 \%$ of uredospore germination. Thus, plant extracts may contribute to the integrated disease management of coffee leaf rust.
\end{abstract}

Key words: Coffea arabica, coffee leaf rust, organic fungicides, secondary metabolites. 


\section{Introduction}

Mexico is among the top 10 coffee bean (Coffea arabica L.) producing countries. In 2018, production reached $860,000 \mathrm{t}$ of coffee beans out of an area of 630,000 ha, and the state of Oaxaca contributed $20 \%$ of the national production (SADER, 2018). Coffee production is affected by leaf rust caused by Hemileia vastatrix, a fungus that reduces production up to $40 \%$. In Mexico, varieties susceptible to this disease, such as Typica, Bourbon, Mundo Novo, Caturra, Garnica, Catuaí, and Pluma Hidalgo, are grown (Hernández-Martínez \& VelázquezPremio, 2016). Uredospores of $H$. vastatrix are the primary inoculum of the disease cycle. Under in vitro conditions, uredospores germinate at minimum, optimal and maximum temperatures of 15.5, 22.0, and $28.5^{\circ} \mathrm{C}$, respectively, in darkness and under low-intensity light (up to 25 luxes) and high humidity ( $>95 \%)$. Uredospore germination of $H$. vastatrix starts after $2.6 \mathrm{~h}$ and stops before $8 \mathrm{~h}$ under in vitro conditions (Nutman et al., 1963; Diniz et al., 2012; Avelino et al., 2015).

The incidence of coffee leaf rust has been mitigated using resistant varieties, biological control, and cultural labor. The most common method to reduce leaf rust is spraying synthetic fungicides, which increases production costs and ecological risks (Avelino \& Rivas, 2013; Hernández-Martínez \& Velázquez-Premio, 2016). Leaf rust affects the economy and threatens the food security of Mexican families whose income depends on coffee. In Mexico, in the last four years, the area cultivated with coffee decreased by approximately 110,000 ha, with leaf rust being an important factor in this loss (SADER, 2018). In this context, it is important to look for alternatives that complement integrated crop management. One of them is the use of plant extracts (Rodríguez et al., 2000), which consist of a mixture of biomolecules with antifungal properties derived from the secondary metabolism of plants (Reddy et al., 2020). The aims of this study were to identify the optimal temperature, $\mathrm{pH}$, incubation time and luminosity for the germination of $H$. vastatrix uredospores and to evaluate the effect of plant extracts on $H$. vastatrix uredospore germination under in vitro conditions.

\section{Materials and methods}

\section{Factors that affect uredospore germination}

Hemileia vastatrix uredospores were collected from 35-year-old coffee plants (Coffea arabica L.; var. Caturra) in a plot belonging to the Instituto Tecnológico del Valle de Oaxaca $\left(17^{\circ} 01^{\prime} \mathrm{N}\right.$, $96^{\circ} 46^{\prime} \mathrm{W}, 1,567 \mathrm{~m}$ altitude) in 2018. A completely randomized design was used with an $8 \times 3 \times 4$ factorial array $\left(\mathrm{T}^{\circ}, \mathrm{pH}\right.$, time): incubation temperatures $\left(18,20,22,24,26,28,30\right.$, and $\left.32{ }^{\circ} \mathrm{C}\right)$, levels of $\mathrm{pH}(3.7,5.7$, and 7.7$)$ in the substrate (potatodextrose-agar, BD Bioxon ${ }^{\mathrm{TM}}$, Mexico) and incubation times $(3,6,12$, and $24 \mathrm{~h})$, all independently evaluated in two light environments (darkness and $15 \mathrm{~W}$ white light). Microphotographs were taken of the uredospores of each treatment with a digital camera (AxioCam ICc1) mounted on a compound microscope (Carl Zeiss, Primo Star). In each image, 3000 uredospores were selected, and the number of germinated spores was recorded. The percentage of germinated uredospores was estimated with the formula $\mathrm{Ug}=[(\mathrm{G} i)(100)] / \mathrm{T} i$, where $\mathrm{Ug}=$ percentage of germinated uredospores and $\mathrm{G} i=$ number of germinated uredospores in the experimental treatment at time $i$. Ti $=$ total uredospores examined in the experimental treatment at time $i$. The data were transformed to $e^{\sqrt{x+1}}$ to fulfil normality (Shapiro-Wilks) and homogeneity of variance (Bartlett). An analysis of variance and separation of means (Duncan, 0.05) were performed with the Statistical Analysis System program 9.0 (SAS Institute, Inc., Cary, NC).

Effect of plant extracts on uredospore germination

The effects of extracts from 10 plant species were evaluated (Table 1). The plants were collected in the state of Oaxaca, Mexico, in 2018. The plants 
were washed with water and dried in the shade $\left(22^{\circ} \mathrm{C} \pm 2{ }^{\circ} \mathrm{C}\right)$ for 30 days. Ethanol and acetone extracts were obtained by mixing $25 \mathrm{~g}$ of dry material with $350 \mathrm{~mL}$ of distilled water, absolute ethanol or acetone. The mixture was placed in an ultrasound sonicator bath (Branson Model 3800) for $3 \mathrm{~h}$. The solvent was removed with a rotavapor (Buchi Model B-100) at $40{ }^{\circ} \mathrm{C}$. Ninety treatments resulting from the interaction of 10 types of plant extracts, three solvents (acetone, ethanol, and water) and three concentrations $(0.5,1.0$, and $2.0 \%)$ were established; each was replicated five times. PDA was prepared ( $\mathrm{pH}$ 5.7) and independently mixed with each of the dosages of the plant extracts. The PDA was poured into Petri dishes, and after $24 \mathrm{~h}$, between 3000 and 3500 uredospores were placed on the media. The dishes were incubated at $23{ }^{\circ} \mathrm{C}$ in constant darkness for $6 \mathrm{~h}$. An absolute control (PDA culture medium without extract) was included. Six hours after seeding, microphotographs were taken of the uredospores of each treatment with a digital camera (AxioCam ICc1) mounted on a compound microscope (Carl Zeiss, Primo Star). In each image, 3000 uredospores were selected, and the number of germinated spores was recorded. The percentage of inhibition of uredospore germination was estimated with the formula:

$$
I=\frac{C-D}{T}(100)
$$

where I = percentage of non-germinated uredospores; $\mathrm{C}=$ number of germinated uredospores in the control treatment at time $i$; and $\mathrm{T}=$ number of germinated uredospores in the experimental treatment at time $i$. A completely randomized experimental design was used with a $10 \times 3 \times 3$ (plant extracts, solvents, and concentrations) factorial array. An analysis of variance was performed with variables transformed to $\mathrm{e}^{(\mathrm{x} / 100)}$ and separation of means (Duncan, 0.05) with the Statistical Analysis System program 9.0 (SAS Institute, Inc., Cary, NC).

\section{Results and discussion}

\section{Factors involved in uredospore germination}

The factors $\left(\mathrm{T}^{\circ}, \mathrm{pH}\right.$, and incubation time), evaluated in darkness and in the presence of light, had a significant $(\mathrm{p}<0.01)$ influence on the germination of $H$. vastratrix uredospores (Table 2). In darkness, the highest percentage of uredospore germination was between 41.70 and $44.95 \%$, which was favored at $\mathrm{pH} 5.7$, under $24 \mathrm{~h}$ of incubation time and at $\mathrm{T}^{\circ}$ between 18 and $24{ }^{\circ} \mathrm{C}$. In the presence of light, the highest percentage of uredospore germination was between 42.92 and $43.41 \%$ and occurred at $\mathrm{pH} 5.7$, with a $24 \mathrm{~h}$ incubation time and at $\mathrm{T}^{\circ}$ between 18 and $20^{\circ} \mathrm{C}$ (Table 3 ). An acidic (3.3) or alkaline (7.7) $\mathrm{pH}$, as well as

Table 1. Plants collected in Oaxaca, Mexico, in 2018 used to extract organic compounds with ethanol, acetone and water.

\begin{tabular}{lccc}
\hline Scientific name & Common name & Family & Organ \\
\hline Acacia farnesiana & Huisache & Fabaceae & Leaves and flower \\
Allium sativum & Garlic & Amaryllidaceae & Fruit \\
Anredera vesicaria & Sacasile & Basellaceae & Root \\
Cestrum sp. & Night blooming jasmine & Solanaceae & Leaves \\
Datura ferox & Fierce thorn apple & Solanaceae & Leaves and seed \\
Mansoa alliacea & Wild garlic & Bignoniaceae & Leaves \\
Ricinus communis & Castor oil plant & Euphorbiaceae & Seeds \\
Thymus vulgaris & Thyme & Lamiaceae & Leaves \\
Tribulus terrestris & Caltrop & Zygophyllaceae & Leaves and flowers \\
Zingiber officinale & Ginger & Zingiberaceae & Root \\
\hline
\end{tabular}


temperatures over $24{ }^{\circ} \mathrm{C}$, did not contribute to uredospore germination (Table 3 ). These results agree with those by Nutman et al. (1963) and Diniz et al. (2012), who reported that, under in vitro conditions, uredospore germination occurs in darkness or in the presence of low-intensity light (up to 25 luxes) at minimum, optimal and maximum $\mathrm{T}^{\circ}$ values of $15.5,22.0$, and $28.5^{\circ} \mathrm{C}$, respectively. These authors stated that in condi- tions of darkness, germination starts after $2.6 \mathrm{~h}$ and stops before $8 \mathrm{~h}$ after inoculation. However, in our study, we found that uredospore germination occurs at $2 \mathrm{~h}$ until $24 \mathrm{~h}$ after inoculation. Not all fungal uredospores germinate; germination depends on the age. Mature uredospores have a higher rate of germination, but this rate decreases exponentially as they age (Nutman et al., 1963; Arroyo et al., 2019).

Table 2. Significance of squared means for germination and inhibition of Hemileia vastatrix uredospores under two conditions of light (low-intensity light and continuous darkness).

\begin{tabular}{|c|c|c|c|c|c|c|}
\hline \multirow{2}{*}{ SV } & \multirow{2}{*}{ DF } & \multicolumn{2}{|c|}{ Light condition } & \multirow{2}{*}{ SV } & \multirow{2}{*}{ DF } & \multirow{2}{*}{$\begin{array}{c}\text { Germination } \\
\text { inhibition }\end{array}$} \\
\hline & & Light & Dark & & & \\
\hline $\mathrm{T}^{\circ}$ & 7 & $241768.8^{* *}$ & $769386.9^{* *}$ & Solvent (D) & 2 & $0.389^{* *}$ \\
\hline $\mathrm{pH}$ & 2 & $590960.1 * *$ & $5452402.4 * *$ & Plant (V) & 9 & $0.733^{* *}$ \\
\hline Time $(\mathrm{t})$ & 3 & $216788.3 * *$ & $995499.6^{* *}$ & Concentration $(\mathrm{C})$ & 2 & $2.088^{* *}$ \\
\hline $\mathrm{T}^{\circ} \times \mathrm{pH}$ & 14 & $232393.7 * *$ & $758082.0 * *$ & $\mathrm{D} \times \mathrm{V}$ & 18 & $0.292^{* *}$ \\
\hline $\mathrm{T}^{\circ} \times \mathrm{t}$ & 21 & $93305.7 * *$ & $136626.0^{* *}$ & $\mathrm{~V} \times \mathrm{C}$ & 18 & $0.356^{* *}$ \\
\hline $\mathrm{pH} \times \mathrm{t}$ & 6 & $205869.4 * *$ & $948356.5^{* *}$ & $\mathrm{D} \times \mathrm{C}$ & 4 & $0.012^{\text {ns }}$ \\
\hline $\mathrm{T}^{\circ} \times \mathrm{pH} \times \mathrm{t}$ & 42 & $90294.1^{* *}$ & $134582.5 * *$ & $\mathrm{D} \times \mathrm{V} \times \mathrm{C}$ & 36 & $0.107^{* *}$ \\
\hline Error & 648 & 4048.9 & $37581.6^{* *}$ & Error & 810 & 0.006 \\
\hline Total & 743 & & & Total & 899 & \\
\hline
\end{tabular}

$\mathrm{SV}=$ source of variation, $\mathrm{DF}=$ degree of freedom, $\mathrm{T}^{\circ}=$ temperature $\left(18,20,22,24,26,28,30\right.$, and $\left.32{ }^{\circ} \mathrm{C}\right), \mathrm{pH}(3.7,5.7$, and 7.7$)$, and $\mathrm{t}=$ incubation time $(3,6,12$, and $24 \mathrm{~h})$. Variables transformed to $e^{\sqrt{x+1}}$ and ${ }^{*} \mathrm{e}^{(\mathrm{x} / 100)}$. **Highly significant $(\mathrm{P}<0.01)$ and ns: Not significant $(\mathrm{P}>0.05)$.

Table 3. Germination (\%) of Hemileia vastatrix uredospores as a function of temperature, $\mathrm{pH}$, and incubation time under artificial light and darkness.

\begin{tabular}{|c|c|c|c|c|c|c|c|c|}
\hline \multirow{2}{*}{$\begin{array}{l}\text { Temperature }\left({ }^{\circ} \mathrm{C}\right) \\
20\end{array}$} & \multicolumn{3}{|c|}{ Dark } & \multicolumn{5}{|c|}{ Light } \\
\hline & 11.64 & \pm & 1.69 & $\mathrm{a}$ & 8.69 & \pm & 1.30 & $\mathrm{a}$ \\
\hline 22 & 11.38 & \pm & 1.84 & $\mathrm{a}$ & 1.80 & \pm & 0.34 & $\mathrm{~b}$ \\
\hline 24 & 10.96 & \pm & 1.69 & $\mathrm{a}$ & 0.44 & \pm & 0.03 & e \\
\hline 18 & 9.36 & \pm & 1.52 & $\mathrm{~b}$ & 8.93 & \pm & 1.56 & $\mathrm{a}$ \\
\hline 26 & 2.89 & \pm & 0.39 & $\mathrm{c}$ & 1.32 & \pm & 0.22 & $b c$ \\
\hline 30 & 0.75 & \pm & 0.09 & $\mathrm{~d}$ & 0.69 & \pm & 0.10 & de \\
\hline 28 & 0.56 & \pm & 0.09 & $\mathrm{~d}$ & 0.39 & \pm & 0.13 & e \\
\hline 32 & 0.35 & \pm & 0.06 & $\mathrm{~d}$ & 1.14 & \pm & 0.18 & $\mathrm{~cd}$ \\
\hline $\mathrm{pH}$ & & & & & & ght & & \\
\hline 5.7 & 16.36 & \pm & 1.16 & $\mathrm{a}$ & 7.49 & \pm & 0.81 & $\mathrm{a}$ \\
\hline 7.7 & 1.79 & \pm & 0.16 & $\mathrm{~b}$ & 1.19 & \pm & 0.13 & $\mathrm{~b}$ \\
\hline 3.7 & 0.36 & \pm & 0.03 & $\mathrm{c}$ & 0.27 & \pm & 0.02 & $\mathrm{c}$ \\
\hline Time & & & & & & ght & & \\
\hline 24 & 9.58 & \pm & 1.18 & $\mathrm{a}$ & 5.76 & \pm & 0.88 & $\mathrm{a}$ \\
\hline 12 & 8.22 & \pm & 1.10 & b & 3.94 & \pm & 0.67 & $\mathrm{~b}$ \\
\hline 6 & 5.61 & \pm & 0.84 & $\mathrm{c}$ & 1.60 & \pm & 0.26 & $\mathrm{c}$ \\
\hline 3 & 1.26 & \pm & 0.23 & $\mathrm{~d}$ & 0.63 & \pm & 0.14 & $\mathrm{~d}$ \\
\hline
\end{tabular}

Means are \pm standard error. Different letters in each factor indicate statistically significant differences (Duncan, $\alpha=0.05$ ). 
Effect of plant extracts on uredospore germination

The plant extracts evaluated in this study had a significant effect $(\mathrm{P}<0.01)$ on uredospore germination (Table 2). Ethanolic and acetone extracts of $T$. terrestris, A. vesicaria, A. farnesiana, Cestrum sp., R. communis, D. ferox, M. alliacea and Z. officinale, at $0.5 \%$, inhibited more than $95 \%$ germination. The same results were obtained with aqueous extracts of $T$. terrestris, A. sativum, A. vesicaria, A. farnesiana, Cestrum sp. and $R$. communis, at $0.5 \%$; Z. officinale, at $1.0 \%$; and M. alliacea and T. vulgaris, at $2.0 \%$ (Figure 1). The biomolecules that plants produce during secondary metabolism are terpenes, phenols, quinones, polyacetylenes, polyenes, alkamides, carbohydrates, organic acids, alkaloids, nonprotein amino acids, glucosinolates, lectins or peptides, which alter the composition of the cell wall and membrane and modify the basic functions of the cells (Silva \& Fernandes, 2010; Reddy et al., 2020). The essential oils and extracts of the plants used in this study have shown antifungal activity against phytopathogenic fungi in previous studies (Silva \& Fernandes, 2010), but there is no evidence that they inhibit the growth and development of $H$. vastatrix, except for $T$. vulgaris, which has previously been reported as an inhibitor of uredospore germination of this fungus (Borges et al., 2012).

It is concluded that uredospores of $H$. vastratrix can germinate in darkness and in the presence of low-intensity light $(15 \mathrm{~W})$ at an optimal temperature of 18 and $24{ }^{\circ} \mathrm{C}$ and $\mathrm{pH}$ 5.7. Germination started before $3 \mathrm{~h}$ and stopped $24 \mathrm{~h}$ after incubation. The plant extracts of A. farnesiana, A. sativum, A. vesicaria, Cestrum sp., D. ferox, M. alliacea, R. communis, T. vulgaris, T. terrestris and Z. officinale reduced the germination of $H$. vastratrix uredospores by $95 \%$ under in vitro conditions. This study provides basic information on the capacity of plant extracts evaluated to inhibit germination of $H$. vastratrix uredospores. This study may contribute to the selection of candidate compounds for the development of new selective natural fungicides for the management of plant diseases in agricultural crops.
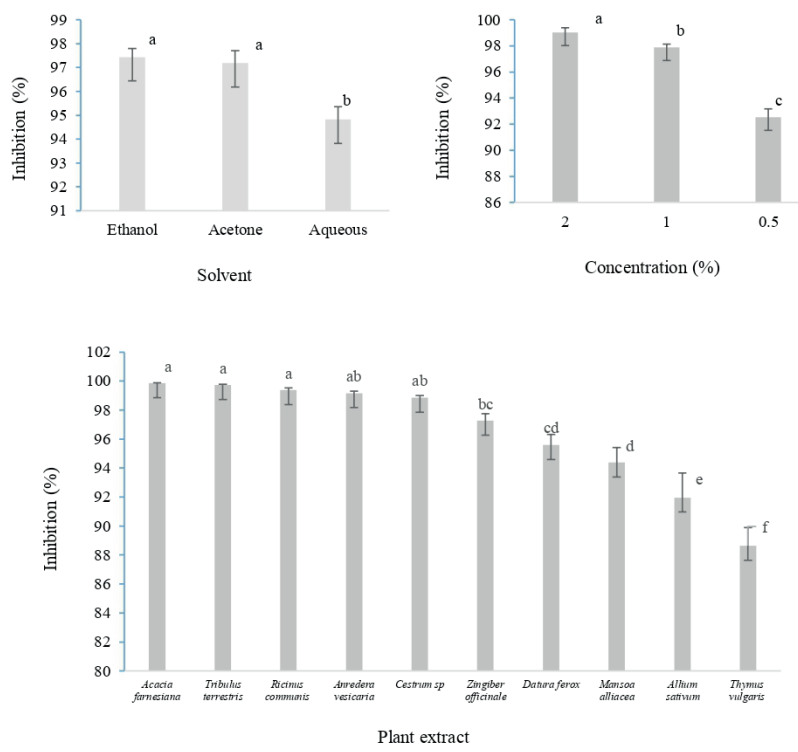

Figure 1. Inhibition (\%) of H. vastatrix uredospore germination by the effect of organic compounds extracted with acetone, ethanol, and water from ten plant species collected in the state of Oaxaca, Mexico, in 2018. Vertical lines at the top of the bars represent standard error. Different letters in each factor indicate statistically significant differences (Tukey, $\alpha=0.05$ ) 


\title{
Resumen
}

\begin{abstract}
M.A. Morales-Antonio, G.M. Santiago-Martínez, A. Vásquez-López, G. RodríguezOrtiz, D. Soto-Castro, S. Lozano-Trejo, y E. Castañeda-Hidalgo. 2021. Germinación de uredosporas de Hemileia vastatrix y su inhibición por efecto de extractos vegetales in vitro. Int. J. Agric. Nat. Resour. 108-114. La roya, causada por Hemileia vastatrix, es la enfermedad más importante del cultivo de café (Coffea arabica L.) en México; ésta ocasiona pérdidas de producción de hasta $40 \%$ y uso de volúmenes considerables de fungicidas sintéticos. Los objetivos de esta investigación fueron identificar la temperatura, $\mathrm{pH}$, tiempo de incubación y luminosidad que inciden en la germinación de uredosporas in vitro; y evaluar el efecto de extractos vegetales sobre su germinación. Se recolectaron uredosporas de plantas de café var. Caturra, cultivadas en el estado de Oaxaca, México, y se sometieron a tratamientos combinando niveles de $\mathrm{T}^{\circ}, \mathrm{pH}$ y tiempo de incubación. Los tratamientos se evaluaron en oscuridad y en luz blanca de baja intensidad $(15 \mathrm{~W})$. Las uredosporas germinaron en ausencia y en presencia de luz. La germinación máxima fue de $44.95 \%$ y ocurrió en $\mathrm{pH}$ de 5.7, temperaturas entre 18 y $24{ }^{\circ} \mathrm{C}$ y tiempo de incubación de $24 \mathrm{~h}$. Se evaluaron 30 extractos vegetales sobre la inhibición de germinación de uredosporas. Los extractos de Tribulus terrestris, Datura ferox, Mansoa alliacea, Ricinus communis y Acacia farnesiana; extraídos con acetona y etanol; inhibieron en $100 \%$ la germinación de uredosporas. Los extractos vegetales pueden contribuir al manejo integrado de la roya en café.
\end{abstract}

Palabras clave: Coffea arabica, fungicidas orgánicos, metabolitos secundarios, roya del café.

\section{References}

Arroyo, E.J., Sanchez, F., \& Barboza, L.A. (2019). Infection model for analyzing biological control of coffee rust using bacterial anti-fungal compounds. Mathematical Biosciences, 307:13-24. doi: 10.1016/j.mbs.2018.10.009

Avelino, J., \& Rivas, G. (2013). La roya anaranjada del cafeto. Retrieved from: https://hal.archivesouvertes.fr/hal-01071036

Avelino, J., Cristancho, M., Georgiou, S., Imbach, P., Aguilar, L., Bornemann, G., Läderach, P., Anzueto, F., Hruska, A.J., \& Morales, C. (2015). The coffee rust crises in Colombia and Central America (2008-2013): Impacts, plausible causes and proposed solutions. Food Security, 7:303321. doi: 10.1007/s12571-015-0446-9

Borges, P.R., Lucas, G.C., Perina, F.J., \& Alves, E. (2012). Essential oils for rust control on coffee plants. Ciência e Agrotecnologia, 36:16-24.

Diniz, I., Talhinhas, P., Azinheira, H.G., Várzea, V., Medeira, C., Maia, I., Petitot, A.S., Nicole, M.,
Fernandez, D., \& Silva, M. do C. (2012). Cellular and molecular analyses of coffee resistance to Hemileia vastatrix and nonhost resistance to Uromyces vignae in the resistance-donor genotype HDT832/2. European Journal of Plant Pathology, 133:141-157. doi: 10.1007/s10658-0119925-9

Hernández-Martínez, G., \& Velázquez-Premio, T. (2016). Análisis integral sobre la roya del café y su control (Integral analysis of coffee rust and its control). Revista Internacional de Desarrollo Regional Sustentable. 1:92-99.

Nutman, F.J., Roberts, F.M., \& Clarke, R.T. (1963). Studies on the biology of Hemileia vastatrix Berk. \& Br. Transactions of the British Mycological Society, 46:27-44. doi: 10.1016/S00071536(63)80005-4

Reddy, P.R.K., Elghandour, M.M.M.Y., Salem, A.Z.M., Yasaswini, D., Reddy, P.P.R., Reddy, A.N., \& Hyder, I. (2020). Plant secondary metabolites as feed additives in calves for antimicrobial stewardship. Animal Feed Science and 
Technology, 264:114469. doi: 10.1016/j.anifeedsci.2020.114469

Rodríguez, A.T., Morales, D., \& Ramírez, M.A. (2000). Efecto de extractos vegetales sobre el crecimiento in vitro de hongos fitopatógenos. Cultivos tropicales, 21:79-82.

SADER (Secretaría de Agricultura y Desarrollo Rural), SIAP (Servicio de Información Agroalimentaria y Pesquera), and SIACON (Sistema de Información Agroalimentaria de Consulta).
(2018). Producción agrícola. Retrieved from: https://www.gob.mx/siap/acciones-y-programas/ produccion-agricola-33119.

Silva, N.C.C., \& Fernandes, J.A. (2010). Biological properties of medicinal plants: a review of their antimicrobial activity. The Journal of Venomous Animals and Toxins Including Tropical Diseases, 16: 402-413. doi: 10.1590/S167891992010000300006

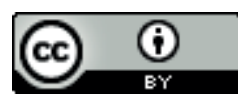

This work is licensed under a Creative Commons Attribution 4.0 International License. 